\title{
Studi Reproduksi Burung Murai Batu (Copsychus malabaricus) pada Penangkaran Lokal di Kota Bengkulu
}

\author{
Reproductive Studies on Murai Batu (Copsychus malabaricus) in Bengkulu Local Captive \\ Breeding
}

\author{
H.D. Putranto, D. Okvianto dan H. Prakoso \\ Jurusan Peternakan Fakultas Pertanian Universitas Bengkulu \\ Jalan W.R. Supratman, Kandang Limun, Bengkulu 38371 \\ E-mail: heridp@unib.ac.id; tora_rendai@yahoo.com
}

\begin{abstract}
A pet, especially birds, has been a part of life style for modern community in Indonesia. Birds which are classified as singing birds or beautiful color birds have been choosen to become a pet. Murai Batu (Copsychus malabaricus), an endemic species of Indonesian aves, has a highly economic values among bird lovers in Indonesia. Unfortunately, its scientific information regarding reproductive status of this species is still unclear. By using a combination of observational method and interview method, a research on Murai Batu's reproductive status was conducted located in Bengkulu's local captive breeding. The purpose of study was to collect a fundamental information on captived Murai Batu's reproductive performances. Observational and interview results were analyzed descriptively. Captived Murai Batu delivered approximately 2.9 eggs during 2 times of egg laying period with about 12.1 day of hatching duration and average of egg hatchability was $94.16 \%$. Cheepers were weaned at age 30 days and female bird can begins to produce more egg approximately after 20.1 days.
\end{abstract}

Key words: local captive breeding, Murai Batu, reproduction.

\begin{abstract}
ABSTRAK
Burung adalah salah satu jenis hewan peliharaan (pet) yang banyak digemari masyarakat di Indonesia saat ini. Banyak jenis burung yang dipelihara karena kemerduan suaranya dan keindahan warna bulunya. Jenis burung peliharaan yang bernilai ekonomis tinggi akan menunjukkan status sosial ekonomi pemeliharanya. Burung Murai Batu (Copsychus malabaricus) termasuk sebagai burung yang digemari dan bernilai ekonomis tinggi. Hingga saat ini masih belum banyak diketahui informasi tentang status reproduksinya baik yang berada di habitat in situ maupun ex situ. Penelitian ini dilakukan dengan menggunakan metode observasi dan wawancara pada penangkar lokal di Kota Bengkulu. Adapun tujuan penelitian ini adalah untuk mengetahui data biologis dasar berupa tampilan reproduksi burung Murai Batu pada penangkaran ex-situ yang dilakukan oleh penangkar lokal di Kota Bengkulu. Data hasil observasi dan wawancara kemudian dianalisis secara deskriptif. Berdasarkan hasil penelitian pada penangkar lokal di Kota Bengkulu dapat disimpulkan bahwa burung Murai Batu menghasilkan telur rata-rata 2,9 butir dalam dua periode bertelur. Lama durasi mengeram rata-rata 12,1 hari dalam dua periode bertelur dengan daya tetas sebesar 94,16\% dalam dua periode bertelur. Anakan burung Murai Batu disapih pada umur 30 hari sedangkan untuk jarak waktu bertelur kembali ratarata 20,1 hari dalam dua periode bertelur.
\end{abstract}

Kata kunci: Burung Murai Batu, reproduksi, penangkaran lokal.

\section{PENDAHULUAN}

Tidak dapat dipungkiri bahwa dengan semakin berkembangnya gaya hidup masyarakat di seluruh pelosok bumi, maka semakin bervariasi pula kebutuhan hidup baik primer, sekunder maupun tambahan/pelengkap guna memenuhi gaya hidup yang dipilih. Hal serupa juga telah berkembang di Indonesia, dimana bagi sebagian masyarakat Indonesia binatang peliharaan (pet) telah menjadi salah satu simbol dari status sosial ekonomi pemeliharanya. Hewan-hewan dengan nilai 
ekonomi tinggi mulai banyak menjadi pilihan dijadikan sebagai peliharaan seperti burung dan reptil.

Burung adalah salah satu jenis hewan peliharaan yang banyak digemari masyarakat saat ini. Banyak jenis burung yang dipelihara karena kemerduan suaranya dan keindahan warna bulunya. Disaat aktifitas seharian yang padat dan melelahkan, bermain dengan hewan peliharaan seperti burung, merupakan salah satu cara yang dilakukan untuk mengurangi stress, karena burung memiliki kicauan yang berirama dan nada yang merdu, sehingga membuat kita menjadi lebih tenang (Sudrajat et al., 2014).

Berdasarkan hasil penelitian Okvianto (2017), terdapat banyak jenis burung kicau yang dijadikan burung peliharaan, salah satunya burung Murai Batu (Copsychus malabaricus). Diketahui bahwa tidak hanya kicauannya yang merdu, warna dan bentuk badannya pun sangat menarik sehingga memiliki nilai ekonomis yang tinggi. Berdasarkan namanya burung Murai Batu memiliki nama yang berbeda-beda dan biasanya diberi nama berdasarkan asal burung Murai Batu itu sendiri. Seperti burung Murai Batu Medan, burung Murai Batu Aceh dan burung Murai Batu Kalimantan. Menurut Welty (1982), burung Murai Batu termasuk ke dalam kelompok burung Thruses yang dikenal bersifat teritorial dan sangat kuat mempertahankan teritorinya. Tipe teritorinya adalah tipe mating, nesting, dan feeding territory. Dengan kata lain, areal yang dipertahankan burung Murai Batu dalam habitatnya adalah tempat untuk melakukan perkawinan, untuk bersarang, dan untuk mencari makan. Selanjutnya ditambahkan oleh
Delacour (1947), burung Murai Batu memiliki daya tarik yang cukup besar untuk dipelihara karena termasuk kelompok burung yang bersuara bagus atau The Best Song Birds.

Basuni dan Setiyani (1989) menyatakan bahwa burung Murai Batu termasuk ke dalam kelompok burung yang sangat disukai orang karena suaranya dengan spesifikasi kicauan. Sampai saat ini diketahui secara umum bahwa penyediaan (supply) burung untuk memenuhi permintaan akan burung Murai Batu sangat bergantung dari hasil alami atau perburuan liar. Hal ini menyebabkan ketersediaan burung Murai Batu di alam semakin sedikit dan sulit didapat. Upaya yang dilakukan oleh masyarakat dalam upaya mengatasi eksploitasi burung yang ada di alam adalah dengan melakukan penangkaran ex-situ. Seperti yang dilakukan oleh Grup Penangkar Pluit BF di Kota Bengkulu yang melakukan penangkaran yang bertujuan untuk memenuhi permintaan pasar akan kebutuhan burung Murai Batu. Melalui upaya penangkaran ex-situ oleh penangkar lokal diharapkan kegiatan perburuan secara ilegal dapat dikurangi.

Salah satu aspek yeng perlu diteliti sebagai dasar dalam usaha penangkaran burung Murai Batu adalah sifat-sifat yang terkait dengan tampilan reproduksi. Beberapa peneliti telah melakukan studi tentang tampilan reproduksi pada burung Cucak Rawa, Tekukur dan Puter (Okvianto, 2017). Akan tetapi studi tentang tampilan reproduksi burung Murai Batu di Indonesia belum ada, termasuk di Kota Bengkulu.

Adapun tujuan dari penelitian ini adalah untuk mengetahui data biologis dasar berupa tampilan reproduksi burung Murai Batu (Copsychus malabaricus) pada penangkaran 
ex-situ yang dilakukan oleh penangkar lokal di Kota Bengkulu.

\section{MATERI DAN METODE}

Penelitian tampilan reproduksi pada burung Murai Batu ini menggunakan metode wawancara (interview) dan observasi langsung pada penangkar lokal yaitu Grup Penangkar Pluit BF milik Bayu Candra S., yang beralamat di Jalan Hibrida X RT.12 RW. 02 Kelurahan Sumur Dewa, Kecamatan Selebar, Kota Bengkulu. Observasi dilakukan dengan pengamatan langsung di lokasi penelitian meliputi kondisi kandang, kondisi burung Murai Batu, jumlah telur dan pengeraman. Aktifitas wawancara dan pengamatan di lokasi telah dilakukan dari tanggal 1 Desember 2016 sampai dengan 28 Pebuari 2017.

Peralatan yang digunakan dalam penelitian ini adalah buku, pena, kamera, tempat pakan dan minum, kotak kayu tempat bertelur dan kandang penangkaran. Bahan yang digunakan dalam penelitian ini adalah 5 (lima) pasang burung Murai Batu yang sudah dewasa kelamin, serta bahan pakan alami yang terdiri dari jangkrik dan kroto, serta pelet. Burung yang diamati adalah burung yang telah didomestikasi dan sudah beradaptasi dalam kandang penangkaran dan lingkungannya. Diketahui bahwa sampel burung aktif secara seksual melalui aktifitas penjodohan terlebih dahulu oleh penangkar dan telah berproduksi sebelumnya.

Variabel yang diamati dalam penelitian ini meliputi kondisi penangkaran, pakan dan minum burung, jumlah telur, durasi mengeram, jumlah telur yang berhasil menetas, umur sapih, dan jarak waktu bertelur kembali. Data hasil observasi dan wawancara kepada penangkar burung Murai Batu yaitu Bapak Bayu Candra disajikan secara deskriptif.

\section{HASIL DAN PEMBAHASAN}

Masyarakat pecinta burung berkicau mengakui bahwa burung Murai Batu adalah salah satu burung berkicau terbaik di dunia yang termasuk dalam famili Turdidae. Burung dari famili Turdidae memiliki kicauan yang baik dengan suara merdu, bermelodi, dan sangat bervariasi (Forum Agri, 2012). Ditambahkan oleh Mua'rif (2012) bahwa berbagai jenis burung family Turdidae pada umumnya memiliki pola warna yang beragam dan menarik. Ukuran tubuhnya rata-rata sedang, kepalanya bulat, kakinya agak panjang, paruhnya runcing dan ramping, dan sayapnya lebar. Pada habitat in situ, Murai Batu lebih banyak dijumpai di dataran rendah sampai ketinggian lebih dari 1.000 mdpl. Klasifikasi Murai Batu menurut Mua'rif (2012) adalah sebagai berikut:

$\begin{array}{ll}\text { Kingdom } & \text { : Animalia } \\ \text { Filum } & \text { : Chordata } \\ \text { Kelas } & \text { : Aves } \\ \text { Ordo } & \text { : Passeriformes } \\ \text { Famili } & \text { : Muscicapidae } \\ \text { Genus } & \text { : Copsychus } \\ \text { Spesies } & \text { : Copsychus malabaricus }\end{array}$

\section{Kondisi Penangkaran}

Penangkaran burung Murai Batu BF telah memiliki izin resmi dari BKSDA Provinsi Bengkulu dengan nomor: SK21/BKSDA BKL-1/2016. Awal penangkaran dilakukan dengan langkah awal 
yaitu menjodohkan burung Murai Batu jantan dengan burung Murai Batu betina. Dalam proses penjodohan kedua burung tersebut dilakukan dengan cara mendekatkan kedua burung dengan menggunakan kandang gantung (Gambar 1).

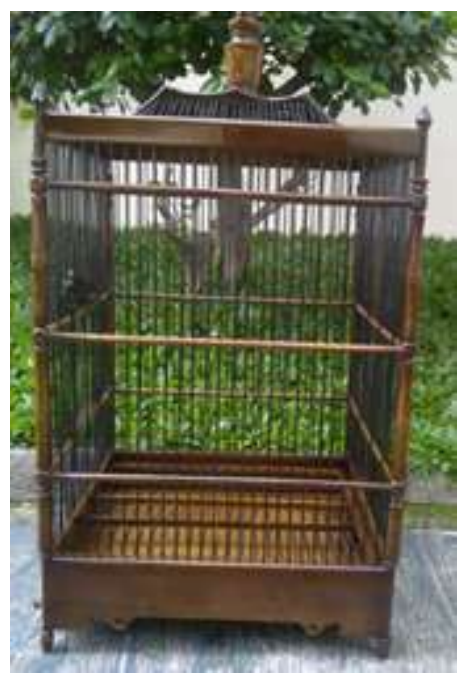

Gambar 1. Kandang gantung mulai batu sebagai tempat perjodohan

Berdasarkan hasil komunikasi pribadi dengan penangkar, burung Murai Batu yang sudah dikatakan berjodoh ditandai dengan kedua burung tersebut selalu berdekatan dan berbunyi bersaut sautan. Berdasarkan pengalaman penangkar maka proses penjodohan memiliki durasi waktu antara 2-3 minggu bahkan bisa berbulan-bulan. Menurut Akdiatmojo (2017) bahwa perjodohan biasanya berlangsung 2 minggu sampai 1 bulan. Selanjutny disebutkan bahwa ciri-ciri indukan yang telah berjodoh ditandai dengan keduanya saling berdekatan setiap hari. Setelah kedua indukan burung Murai Batu telah siap kawin, kedua indukan tersebut dimasukkan ke dalam kandang penangkaran yang berukuran 1 x 2 × $2 \mathrm{~m}^{2}$ untuk melakukan perkawinan.

Menurut Asmari (2016), beberapa faktor yang menentukan keberhasilan dalam penangkaran burung Murai Batu adalah sebagai berikut:

\section{Kondisi indukan}

Idealnya indukan yang akan ditangkarkan adalah Murai Batu yang sudah berumur 1-2 tahun. Diasumsikan pada saat tersebut burung sudah memasuki fase dewasa kelamin dan siap bereproduksi melalui sistem perjodohan.

\section{Kondisi kandang}

Kandang dibuat senyaman mungkin untuk kedua indukan yaitu dengan cara membuat kandang yang tidak terlalu luas, diberi pohon kecil sebagai tempat bertengger. Sirkulasi udara lancar dan sinar matahari masuk ke dalam kandang penangkaran.

\section{Perjodohan.}

Pada prinsipnya perjodohan dilakukan secara perlahan mulai dari perkenalan, pendekatan dan terakhir pencampuran kedua indukan.

\section{Pemberian Pakan dan Minum}

Menurut Rasyaf (1996), pakan merupakan penunjang produktivitas ternak. Berdasarkan hasil observasi di lapangan peneliti mencatat bahwa pakan yang diberikan pada burung Murai Batu di penangkaran antara lain jangkrik (Gambar 2), kroto (Gambar 3) dan pelet. Pada saat burung Murai Batu belum menghasilkan telur, diberi pakan berupa jangkrik dan pakan pabrikan berupa pelet yang memiliki kandungan protein cukup tinggi dengan harapan burung Murai Batu cepat mengalami birahi. Kandungan protein kasar tertinggi dalam bahan kering pakan dikandung oleh jangkrik yaitu sebesar 73,05\%, diikuti 
kroto sebesar 53,16\%, dan pakan buatan sebesar 44,62\% (Nahrowi et al., 2001).

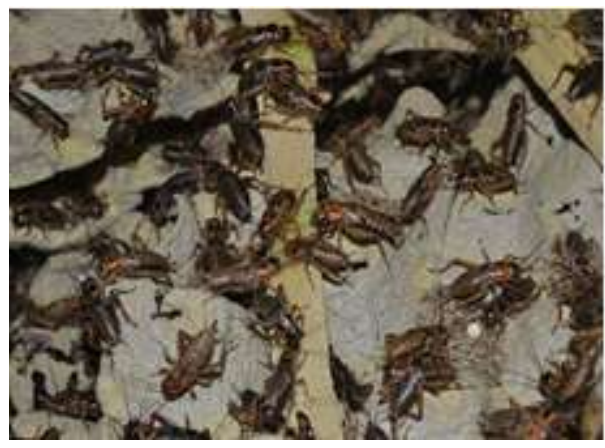

Gambar 2. Pakan burung berupa jangkrik

Pemberian kroto atau telur semut Rangrang diberikan pada saat burung Murai Batu baru menetas sampai umur satu minggu. Pemberian kroto bertujuan agar mempermudah indukan melolo (menyuapi anakan). Kroto yang diberikan adalah kroto segar, harus berkualitas, tidak lengket, berwarna cerah, tidak bercampur dengan jenis semut lain dan tidak mengandung larva yang berukuran besar. Setelah umur satu minggu pemberian kroto dihentikan karena dianggap anakan burung Murai Batu sudah mampu mencerna jangkrik.

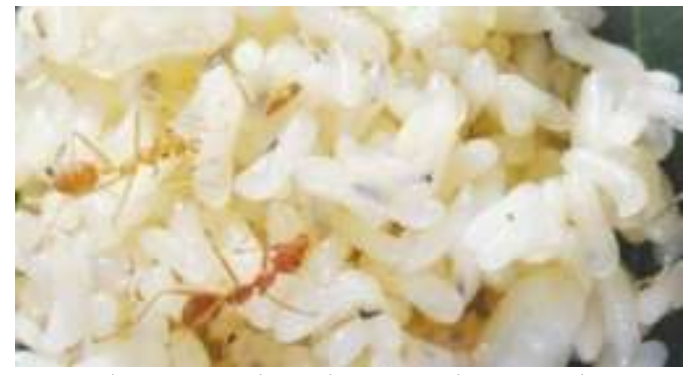

Gambar 3. Pakan burung berupa kroto

Pemberian pakan bertujuan untuk mendongkrak tingkat pertumbuhan, stamina dan kebugaran burung, serta meningkatkan sistem kekebalan tubuh terhadap serangan penyakit yang semuanya harus diberikan dalam keadaan hidup sehingga nutrisi dan cita rasanya tetap terjaga (Widyaningsih, 2008).

Pemberian minum dilakukan dengan cara menggunakan nampan plastik yang diisi setengah bagian. Air minum diganti setiap hari dengan air yang masih segar supaya lebih steril dan terhindar dari parasit yang bisa mengganggu kesehatan burung. Oleh karena itu, ketersediaan air minum segar menjadi salah satu hal yang tidak boleh dilupakan dalam pemberian pakan pada burung Murai Batu. Forum Agri (2012) menyatakan bahwa dalam satu hari rata-rata burung akan membutuhkan air minum sebanyak 4-5 kali jumlah pakannya. Air sangat dibutuhkan dalam proses metabolisme tubuh, termasuk mengatur temperatur (panas) tubuh, mempertahankan keseimbangan volume darah dan melumatkan makanan dalam proses pencernaan. Pemberian air dengan menggunakan nampan tidak hanya untuk minum saja tetapi juga untuk tempat mandi burung. Sesuai dengan habitat aslinya bahwasanya burung Murai Batu terbiasa melakukan aktifitas mandi di pagi hari.

\section{Tampilan Reproduksi}

Data tampilan reproduksi 5 pasang burung Murai Batu yang menjadi sampel observasi dapat dilihat pada Tabel 1.

Telur yang dihasilkan selama penelitian berwarna kebiruan dengan totol-totol coklat seperti telur puyuh dan menghasilkan telur 2-4 butir dalam satu periode bertelur atau rata-rata 2,9 butir dalam dua periode bertelur. Jalil dan Turut (2012) menyatakan burung Murai Batu dapat bertelur 2-3 butir dalam sekali pengeraman. Selanjutnya diketahui bahwa induk Murai Batu yang masih muda, biasanya bertelur hingga 3 butir, sedangkan Murai Batu yang sudah tua hanya bertelur 2 butir. Sedangkan pada penelitian pada burung Cucak Rawa di penangkaran ex-situ yang dilakukan 
oleh Zulkarnain et al. (2015), jumlah telur menggunakan burung Tekukur dalam dalam satu periode bertelur menghasilkan 2 penangkaran menghasilkan 1-2 butir telur dan butir telur. Dalam penelitian lain yang pada burung Puter sebanyak 1-3 butir telur dilakukan oleh Masyud (2007) dengan dalam satu kali peristiwa bertelur.

Tabel 1. Tampilan Reproduksi Burung Murai Batu di penangkaran ex-situ selama penelitian

\begin{tabular}{|c|c|c|c|c|c|c|c|}
\hline Burung & $\begin{array}{l}\text { Periode } \\
\text { Bertelur }\end{array}$ & $\begin{array}{c}\text { Jumlah } \\
\text { Telur } \\
\text { (butir) }\end{array}$ & $\begin{array}{c}\text { Durasi } \\
\text { Mengeram } \\
\text { (hari) }\end{array}$ & $\begin{array}{c}\text { Jumlah } \\
\text { Menetas } \\
\text { (ekor) }\end{array}$ & $\begin{array}{c}\text { Daya } \\
\text { Tetas } \\
(\%)\end{array}$ & $\begin{array}{c}\text { Lama } \\
\text { Betelur } \\
\text { Kembali } \\
\text { (hari) }\end{array}$ & $\begin{array}{l}\text { Umur } \\
\text { Sapih } \\
\text { (hari) }\end{array}$ \\
\hline \multirow{2}{*}{1} & 1 & 3 & 11 & 2 & 66,66 & 13 & 30 \\
\hline & 2 & 3 & 11 & 3 & 100 & 13 & 30 \\
\hline \multirow{2}{*}{2} & 1 & 2 & 10 & 2 & 100 & 12 & 30 \\
\hline & 2 & 3 & 13 & 3 & 100 & 12 & 30 \\
\hline \multirow{2}{*}{3} & 1 & 4 & 12 & 3 & 75 & 29 & 30 \\
\hline & 2 & 3 & 12 & 3 & 100 & 27 & 30 \\
\hline \multirow{2}{*}{4} & 1 & 3 & 13 & 1 & 33,33 & 17 & 30 \\
\hline & 2 & 3 & 14 & 2 & 66,66 & 23 & 30 \\
\hline \multirow{2}{*}{5} & 1 & 2 & 12 & 2 & 100 & 19 & 30 \\
\hline & 2 & 3 & 12 & 3 & 100 & 20 & 30 \\
\hline Rerata & & 2,9 & 12,1 & 2,3 & 94,16 & 20,1 & 30 \\
\hline
\end{tabular}

Ada beberapa faktor yang diduga berpengaruh terhadap jumlah telur dalam satu kali peristiwa bertelur diantaranya umur burung, berat badan, makanan, kondisi kesehatan dan lingkungan kandang (luas, suhu dan kelembaban serta gangguan lingkungan) (Etches, 1996; Parker, 1969). Umumnya indukan betina akan mengerami telur setelah telur kedua dikeluarkan atau bahkan setelah semua telur dikeluarkan baru indukan akan mengerami (Hamiyanti et al., 2011).

Data tentang durasi mengeram dari hasil penelitian ini untuk kelima indukan adalah antara 11-14 hari atau rata-rata 12,1 hari dalam dua periode bertelur. Ini sesuai dengan pendapat Suminarsih (2006) yang menyatakan bahwa umumnya burung berkicau yang ditangkarkan mengerami telurnya selama 1415 hari. Begitu pula pendapat Akdiatmojo (2017) yang menyatakan bahwa indukan burung Murai Batu mengerami telur selama 14 hari.

Masa mengeram bisa dikatakan masa kritis karena telur yang dierami bisa pecah atau dibuang dari sarang jika ada yang membuatnya ketakutan. Oleh karena itu, lingkungan harus dijaga dari gangguan dan tetap terkendali. Dalam kondisi ini lingkungan dan pemberian pakan untuk indukan harus teratur. Kondisi lingkungan berpengaruh pada kenyamanan indukan betina, suhu pengeraman dan agresifitas indukan (Akdiatmojo, 2017).

Selanjutnya diketahui bahwa pada saat mengeram, indukan sebaiknya jangan terlalu sering dilihat karena dapat mengganggu proses mengeram yang dilakukan oleh indukan. Apabila indukan terlalu sering mendapat gangguan pada waktu mengeram akan menyebabkan stress sehingga indukan akan enggan mengerami dan bahkan bisa 
membuang telur tersebut sehingga menyebabkan telur gagal menetas.

Data tampilan reproduksi pada Tabel 1 menunjukan bahwasanya daya tetas dari ke 5 indukan cukup tinggi. Hal ini dapat dilihat dari jumlah telur yang dihasilkan dalam dua periode sebanyak 29 butir dan berhasil menetas sebanyak 24 butir atau 94,16\% untuk dua periode bertelur. Akdiatmojo (2017) menyatakan bahwa dalam proses penangkaran burung Murai Batu, ada beberapa hal yang menyebabkan tidak semua telur berhasil menetas diantaranya indukan sering meninggalkan sarang, suhu udara yang dingin, dan kekurangan asupan pakan. Selanjutnya ditambahkan oleh Etches (1996) yang menyatakan bahwa ada beberapa faktor yang diduga berpengaruh terhadap daya tetas telur antara lain umur indukan, suhu dan kelembaban kandang, dan kualitas pakan. Ditambahkan oleh Suminarsih (2006) bahwa aktivitas perkembangbiakan burung-burung tropis termasuk Murai Batu secara alami dimulai pada akhir musim hujan antara bulan Januari dan berlanjut sampai akhir bulan Agustus.

Menurut Hikmat (2016) terdapat 3 faktor yang mempengaruhi daya tetas telur yaitu kualitas telur yang akan dipengaruhi oleh kualitas pakan yang diberikan pada induk dan tingkat kematangan telur. Selanjutnya faktor lingkungan yaitu kualitas air yang terdiri dari suhu, oksigen, karbondioksida, amonia dan lain lain. Faktor terakhir yaitu getaran yang terlalu kuat yang menyebabkan terjadinya benturan yang keras di antara telur atau benda lainnya sehingga mengakibatkan telur pecah.

Dari hasil observasi dan komunikasi pribadi dengan penangkar diketahui bahwa anakan akan disapih pada umur 30 hari (umur sapih 30 hari). Sapih dalam penelitian ini yaitu memisahkan anakan dari induknya oleh penangkar yang dianggap telah mampu hidup tanpak induknya. Tujuan penyapihan pada umur 30 hari adalah anakan pada saat disapih tidak perlu disuap lagi. Sehingga kematian dalam perawatan anakan akan berkurang dibanding disapih pada umur 7 hari, dan harga jualnya cukup tinggi.

Menurut Asmari (2016), secara umum para penangkar menyapih anakan untuk diloloh tangan setelah anakan berumur 7 hari dari waku pertama kali menetas. Hal tersebut adalah waktu yang ideal apabila penangkar ingin meloloh sendiri anakan tersebut. Apabila penangkar ingin agar anakan dilolohkan oleh induknya, maka penyapihan dilakukan setelah anakan tersebut mulai belajar makan sendiri sekitar usia dua bulan. Pada penelitian yang dilakukan oleh Zulkarnain et al. (2015) dengan menggunakan burung Cucak Rawa pada penangkaran ex-situ, umur penyapihan dilakukan pada umur 5 hari dengan tujuan agar indukan segera bereproduksi lagi.

Akdiatmojo (2017) menyatakan bahwa penyapihan anak burung Murai Batu dilakukan ketika anakan sudah berumur 1 minggu, tetapi belum mencapai 10 hari. Anakan baru menetas sangat sensitif sehingga rentan terserang penyakit. Jika penyapihan dilakukan pada anakan yang berumur kurang dari satu minggu, kondisi anakan terlalu lemah dan menyulitkan untuk pemberian pakan. Sementara itu, penyapihan pada anakan berumur lebih dari 10 hari menyebabkan anakan takut terhadap manusia. Akibatnya, anakan menolak untuk disuapi oleh penangkar, padahal saat itu 
anakan masih belum bisa makan sendiri (Gambar 4).

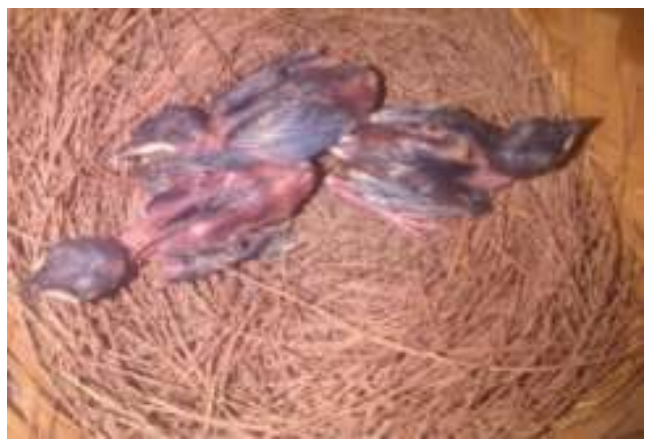

Gambar 4. Anakan Burung Murai Batu prasapih

Setelah menetas anakan diasuh oleh induknya. Pada saat burung baru menetas yang ditandai dengan jatuhnya cangkang telur dari glodok, indukan akan melolo (menyuapi) anaknya dengan kroto yang sebelumnya diberikan di dalam kandang penangkaran. Pemberian kroto dilakukan selama 1 minggu dan seterusnya indukan akan menyuapi anaknya dengan jangkrik yang disediakan sebagai pakan indukan. Sebelum menyuapi anaknya dengan jangkrik, induk burung Murai Batu membanting-banting jangkrik pada tanah dengan paruhnya untuk membunuh dan melunakkan tubuh jangkrik agar mudah dimakan oleh anaknya (Zulkarnain et al., 2015).

Data hasil penelitian pada Tabel 1 didapati bahwa burung Murai Batu bertelur kembali sekitar 12-29 hari setelah anakan menetas (Gambar 5) atau rata-rata 20,1 hari dalam dua periode bertelur. Pada penelitian didapati bahwa tiap indukan burung Murai Batu memiliki siklus reproduksi yang berbeda. Diasumsikan bahwa penyebab berbedanya jarak siklus reproduksi ini antara lain karena pengaruh dari pakan, musim, dan individu burung itu sendiri. Menurut Soenanto (2002), secara alamiah setiap makhluk hidup memiliki siklus reproduksi yang berbeda seperti halnya manusia dan hewan. Sedangkan menurut Asmari (2016), setelah anakan disapih oleh penangkar untuk diloloh sendiri, biasanya 3 sampai 5 hari indukan akan mulai menyusun sarang kembali dan mulai kawin setelah sarang tersebut berbentuk sempurna.

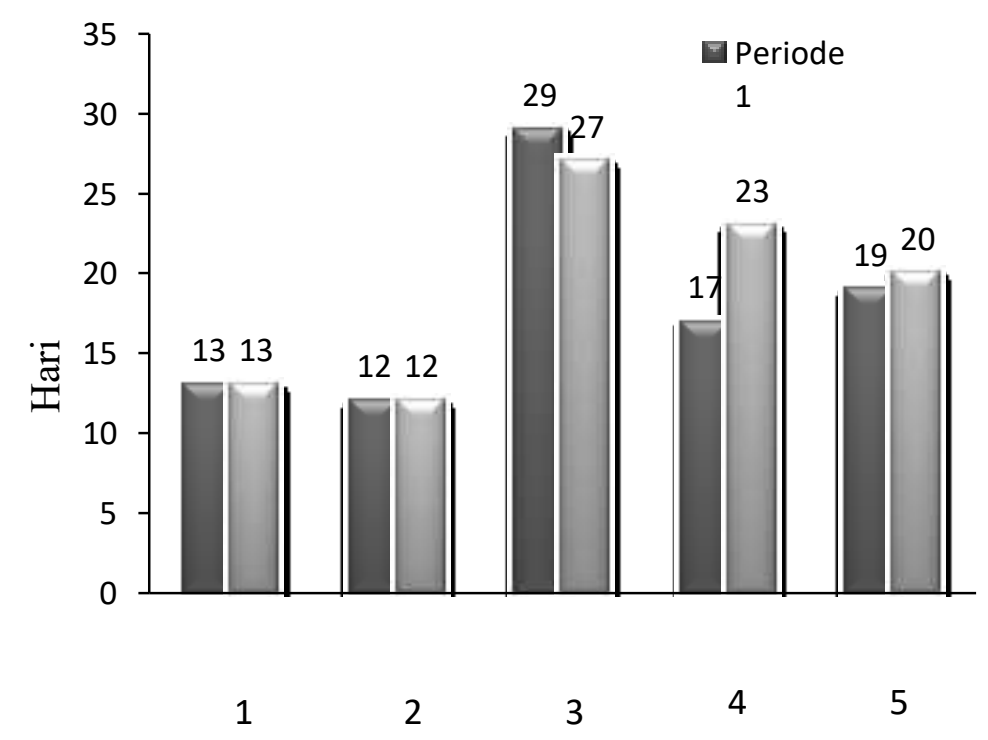

Gambar 5. Grafik lama bertelur kembali burung Murai Batu 
Berdasarkan kondisi jarak bertelur seperti itu maka dalam keadaan normal burung Murai Batu dalam penangkaran dapat bertelur setiap bulannya, tetapi ada waktu tertentu burung Murai Batu tidak berproduksi. Ketika burung Murai Batu mengalami rontok bulu atau mabung, burung Murai Batu dipisah dari pejantan sehingga tidak menghasilkan telur. Penanganan ini berbeda dengan kebiasaannya di habitat in situ yang cenderung dipengaruhi oleh iklim sehingga bertelur pada bulan-bulan tertentu. Pada penelitian yang dilakukan oleh Zulkarnain et al. ( 2015) dengan menggunakan burung Cucak Rawa ex situ diketahui bahwasanya burung tersebut bertelur kembali dengan rata-rata 27,8 hari. Sedangkan pada burung Puter dan Tekukur diketahui bahwa burung Tekukur bertelur kembali dalam keadaan normal yaitu 48,79 hari, relatif lebih lama dibanding burung Puter yakni 43,22 hari (Masyud, 2007). Faktor yang berpengaruh kuat terhadap pola reproduksi antara habitat in situ dan ex situ adalah faktor pakan. Terutama yang berkaitan dengan ketersediaan pakan di alam untuk memenuhi kebutuhan berproduksi.

\section{KESIMPULAN}

Berdasarkan hasil penelitian pada penangkar lokal di Kota Bengkulu dapat disimpulkan bahwa burung Murai Batu menghasilkan telur rata-rata 2,9 butir dalam dua periode bertelur. Lama durasi mengeram rata-rata 12,1 hari dalam dua periode bertelur dengan daya tetas sebesar 94,16\% dalam dua periode bertelur. Anakan burung Murai Batu disapih pada umur 30 hari sedangkan untuk jarak waktu bertelur kembali rata-rata 20,1 hari dalam dua periode bertelur.

\section{DAFTAR PUSTAKA}

Akdiatmojo, S. 2017. Panduan menangkarkan Murai Batu. Agro Media Pustaka. Jakarta.

Asmari, A. 2016. Memilih dan mencetak Murai Batu berprestasi. CV Idzhar. Bandung.

Basuni, S. dan Setiyani. 1989. Studi perdagangan burung di Pasar Pramuka, Jakarta dan teknik penangkapan burung di alam. Media Konservasi. 2 (2): 9-18.

Delacour, J. 1947. Birds of Malaysia. The Mac-Millan Company. New York.

Etches, R. J. 1996. Reproduction in Poultry. Cab International. Canada.

Forum Agri. 2012. Pedoman lengkap menangkar dan mencetak Murai Batu kelas jawara. Cahaya atma pustaka. Yogyakarta.

Hamiyanti, A. A., A. Putra, dan A. P. Muharlien. 2011. Pengaruh jumlah telur terhadap bobot telur, lama mengeram, fertilitas serta daya tetas telur burung Kenari. Ternak Tropika. 2 (1): 95-101.

Hikmat. 2016. http://kliksma.com/2016/04/ sebutkan-3-faktor-yang-mempengaruhidaya-tetas-telur.html. Diakses pada tanggal 23 Januari 2018.

Jalil, A. dan R. Turut. 2012. Sukses beternak Murai Batu. Penebar Swadaya. Jakarta

Masyud, B. 2007. Pola reproduksi burung Tekukur (Streptopelia chinensis) dan burung Puter (Streptopelia risoria) di penangkaran. Media Konservasi. XII (2): $80-88$.

Mua'rif, Z. 2012. Rahasia penangkaran burung Murai Batu. Lyli Publisher. Yogyakarta. 
Masyud, B. 2007. Pola reproduksi burung Tekukur (Streptopelia chinensis) dan burung Puter (Streptopelia risoria) di penangkaran. Media Konservasi. XII (2): 80-88.

Mua'rif, Z. 2012. Rahasia penangkaran burung Murai Batu. Lyli Publisher. Yogyakarta.

Nahrowi, R., Riduan dan L.A. Sofyan. 2001. Pemberian berbagai jenis pakan untuk mengevaluasi palatabilitas, konsumsi, protein dan energi pada kadal (Mabouya multifasciata) dewasa. Biodiversitas. 2 (1): 98-103.

Okvianto, D. 2017. Tampilan reproduksi burung murai batu (Copsychus malabaricus) pada penangkaran di Kota Bengkulu. Skripsi. Jurusan Peternakan, Fakultas Petanian, Universitas Bengkulu.

Parker, J.E. 1969. Reproduction physiology in poultry dalam: Reproduction in farm animals. Second Edition. Editor ESE. Hafez. Lea and Febiger. Philadelphia.
Rasyaf, M. 1996. Memasarkan hasil peternakan. Penebar Swadaya. Jakarta.

Soenanto, A. 2002. Teknik menangkar Lovebird. EFFHAR. Semarang.

Sudrajat, D., D. Kardaya., E. Dihansih. dan S.F.S. Puteri. 2014. Performa produksi telur burung puyuh yang diberi ransum mengandung kromium organik. Buletin Penelitian Universitas Djuanda. 19 (4): 257-262.

Suminarsih, E. 2006. Memelihara, melatih, dan menangkar burung ocehan. Penebar Swadaya. Jakarta.

Widyaningsih, A. 2008. Pakan burung. Penebar Swadaya. Jakarta.

Welty, J. C. $1982 . \quad$ The life birds. $3^{\text {rd }}$ ed. CBS College Publishing. USA.

Zulkarnain, D., W. Bebas. dan I.G.N.B.T. Laksana. 2015. Performans reproduksi burung cucak rawa (Pycnonotus zaylanicus) pada penangkaran secara $e x-$ situ. Indonesia Medicus Veterinus. 4 (2): 139-147. 